\title{
Distribuição diatópica dos ditongos diante de $<$ s $>$ no corpus do ALiB: uma contribuição geolinguística
}

\author{
Diatopical distribution of diphthongs before $<s>$ on the corpus of ALiB: a \\ geolinguistic contribution
}

\author{
Amanda dos Reis Silva \\ Universidade Federal do Recôncavo da Babia \\ Amargosa, Bahia, Brasil
}

\begin{abstract}
Resumo: Este estudo trata da distribuição diatópica da ditongação diante de $<\mathrm{S}>$ em 22 cidades da Bahia, a partir do corpus do Atlas Linguístico do Brasil (ALiB). Foram observadas respostas a seis perguntas do Questionário Fonético-Fonológico $(\mathrm{QFF})$ voltadas à ditongação e, depois, foi feita uma análise geral, com base em 5.001 dados de sílabas fechadas por $<\mathrm{S}>$ obtidas de toda a gravação do QFF e do Questionário SemânticoLexical (QSL). Os resultados para as seis respostas são expostos em cartas linguísticas que demonstram diferenças diatópicas significativas. Da verificação de todos os demais contextos estudados, por meio de análise quantitativa, é possível identificar quatro diferentes comportamentos dentre as cidades. São destaques Salvador e Santo Amaro, localidades em que o fenômeno é expressivo; Vitória da Conquista, Carinhanha e Santana, por sua vez, apresentam forte restrição às vogais ditongadas.
\end{abstract}

Palavras-chave: Ditongação diante de <S>. Atlas linguístico do Brasil. Geolinguística.

\begin{abstract}
This study presents the diatopical distribution of diphthongization before $<\mathrm{S}>$ in 22 cities in Bahia, from the corpus of Linguistic Atlas of Brazil (ALiB). There were observed answers to six questions of the Phonetic-Phonological Questionnaire concerned to the diphthongization, then a general analysis, based on 5.001 data of syllables closed by $<\mathrm{S}>$, was made. The results for the six answers are exposed in linguistic maps that show significative diatopical differences. From the verification of all studied contexts, by the quantitative analysis, it is possible to identify four different behaviors among the cities. We highlight that Salvador and Santo Amaro, localities where the phenomenon is more expressive; and Vitória da Conquista, Carinhanha and Santana, in their turn, presents restriction to the diphthongized vowels.
\end{abstract}

Keywords: Diphthongization before $<\mathrm{S}>$. Linguistic atlas of Brazil. Geolinguistics.

\section{INTRODUÇÃO}

Este artigo tem por objetivo averiguar a distribuição diatópica da ditongação diante de $<$ S $>$ no Estado da Bahia, a partir das elocuções de informantes nativos de 22 cidades, integrantes da rede de pontos do Projeto Atlas Linguístico do Brasil (ALiB). Ao priorizar

*Professora Doutora - Universidade Federal do Recôncavo da Babia, Amargosa, Bahia, Brasil. E-mail: amandaresi@gmail.com. 
a interface diatópica, sob a ótica da Dialetologia e do seu método, a Geografia Linguística, o estudo exporá os resultados encontrados através de cartas linguísticas.

Percebe-se o fenômeno em exemplos tais como os destacados adiante:

(i) INQ. - E... Desse tamanho?

INF. - Pão francêis [fPeusejs].

INQ. - E tem outro nome? Quando você vai na padaria, que você quer pedir esse assim, menor... Você diz...?

INF. - Pão cacetinho.

INQ. - Aí você fala como, geralmente? Ai, eu quero dez...

INF. - Deiz [ $\cup \mathrm{d} \varepsilon \mathrm{j}$ s] cacetinho.

(Mulher, faixa etária I, natural de Salvador)

(ii) INF. - O acendedô ele não acende, só faiz [ Ufajs]... Saí a faísca e cende o gáis [Ugajs].

(Homem, faixa etária II, natural de Caravelas)

A ditongação diante de $<\mathrm{S}>$ é uma das marcas adquiridas pela língua portuguesa falada no Brasil e que, assim como tantos outros aspectos fonético-fonológicos, lexicais, morfossintáticos e pragmáticos, é responsável por revelar diferenças entre o Português Brasileiro (PB) e o Português Europeu (PE). É o que já informava, por exemplo, Leite de Vasconcelos (1970 [1901]), em sua tese de doutoramento, Esquisse d'une dialectologie portugaise, do início do século XX. Dentre as modificações sofridas pelo "dialeto brasileiro", no âmbito da Fonologia, estaria a ditongação diante de $<\mathrm{S}>$ : “[...] on ajoute un $i$ à la syllabe finale de certains mots terminés par $-\hat{\mathrm{e}}: f e i=*$ fê $=$ fez, trei $=*$ trê $=$ três, france $i=*$ France $=$ francês..." (VASCONCELOS, 1970 [1901], p. 133, grifos do autor).

Essa visão do fenômeno enquanto uma inovação é reiterada por outros gramáticos e filólogos do Brasil, que trataram das especificidades do PB, como Ismael de Lima Coutinho (1974 [1938]), Sousa da Silveira (1940), Chaves de Melo (1946), Câmara Jr. (2008 [1953]), Silva Neto (1963) e outros. Aparece, ainda, nos escritos de outros estrangeiros, como em Révah (1958), e na gramática de Vásquez Cuesta e Mendes da Luz (1971 [1949]). Alguns desses autores associam a ditongação ao processo de palatalização do $<\mathrm{S}>$ na fala

1 "Acrescenta-se um $i$ à sílaba final de algumas palavras terminadas por $-\hat{e}: f e i=*$ fê $=$ fez, trei $=*$ trê $=$ três, france $=*$ France $=$ francês...” (VASCONCELOS, 1970 [1901], p. 133, tradução minha). 
carioca $^{2}$ e a maior parte deles retrata a presença do fenômeno na escrita oitocentista, a partir da interpretação de rimas de poetas parnasianos e românticos ${ }^{3}$.

Ainda que haja esses comentários acerca desse tipo de ditongação em muitos textos referenciais sobre a língua portuguesa, poucas foram as investigações dialetológicas e sociolinguísticas que tomaram o fenômeno como objeto de estudo. Boa parte dos estudos se desenvolveram em áreas do Sul - como exemplificam os trabalhos de Leiria (1995, 2000), Tasca (2005) e Haupt $(2007,2008)$ - e do Sudeste do país, em específico no Rio de Janeiro (CALLOU; LEITE; MORAES, 1998, 2003a, 2003b).

Nesse sentido, diante da escassez de evidências com relação à distribuição diatópica de um fenômeno que singulariza o português falado no Brasil, bem como da falta de conhecimento sistematizado sobre os seus condicionamentos estruturais e extralinguísticos, foi desenvolvida, na Universidade Federal da Bahia (UFBA), com base nos dados do Projeto ALiB, a dissertação $A$ ditongação em sílabas fechadas por / $/$ nas trilhas das capitais brasileiras (SILVA, 2014). Àquela altura, havia o objetivo de verificar a distribuição das vogais ditongadas nas 25 capitais ${ }^{4}$ investigadas pelo ALiB, fornecendo, assim, uma visão do fenômeno, ainda que generalista, de Norte a Sul do país, tomando por base a fala de 200 informantes, socialmente estratificados.

Os resultados, obtidos mediante variadas análises estatísticas efetuadas com o auxílio do GoldV arb 2001 (LAWRENCE; ROBINSON; TAGLIAMONTE, 2001), revelaram caminhos para que a ditongação diante de $<\mathrm{S}>$ seja vista como um fenômeno que particulariza falares no Brasil. A distribuição diatópica do fenômeno demonstrou que a ditongação é desfavorecida nas capitais do Sul brasileiro, as quais são seguidas pelas capitais do Centro-Oeste, do Sudeste (à exceção do Rio de Janeiro) e por Belém e Macapá, ao Norte do país. O estudo revelou também que há cidades na Região Norte (Boa Vista, Porto Velho e Rio Branco) em que se percebe um comportamento intermediário quanto ao fenômeno. Por fim, nas capitais do Nordeste brasileiro, no Rio de Janeiro e em Manaus, os pesos relativos indicaram forte prevalência da ditongação das vogais.

A Figura 1, que revela um primeiro tratamento geolinguístico dado ao fenômeno, demonstra a distribuição diatópica da ditongação diante de $<\mathrm{S}>$ nas capitais brasileiras ${ }^{5}$.

\footnotetext{
${ }^{2}$ Conforme apontam os estudos de Bisol (1989, 2012), o processo de ditongação, do ponto de vista do modelo de Geometria de Traços, poderia ser explicado como um caso de espraiamento do traço [ + coronal], subjacente a qualquer articulação do $<\mathrm{S}>\mathrm{em}$ coda. Assim, do ponto de vista fonológico, não haveria, necessariamente, uma correlação entre ditongação e palatalização da consoante. Ademais, os resultados dos estudos de Silva $(2014,2018)$ demonstram que a ditongação vocálica tende a não se manifestar diante de consoante palatal.

${ }^{3}$ Sousa da Silveira (1940), por exemplo, cita rimas de Cassimiro de Abreu (entre nus e azuis), Gonçalves Dias (entre jamais e voraz) e Castro Alves (entre vãs e mães).

${ }^{4}$ Por questões referentes à história e à demografia, não são consideradas pela rede de pontos do ALiB as capitais do Distrito Federal (Brasília) e do Tocantins (Palmas).

5 Nesta carta, os pesos relativos atribuídos para as capitais foram divididos em cinco categorias, considerando-se o intervalo de classe entre 0,08 (menor valor encontrado, em Porto Alegre) e 0,90 (maior valor, em Salvador).
} 


\section{das Letras}

Fig.1 - A ditongação diante de $<\mathrm{S}>$ nas capitais brasileiras: distribuição diatópica

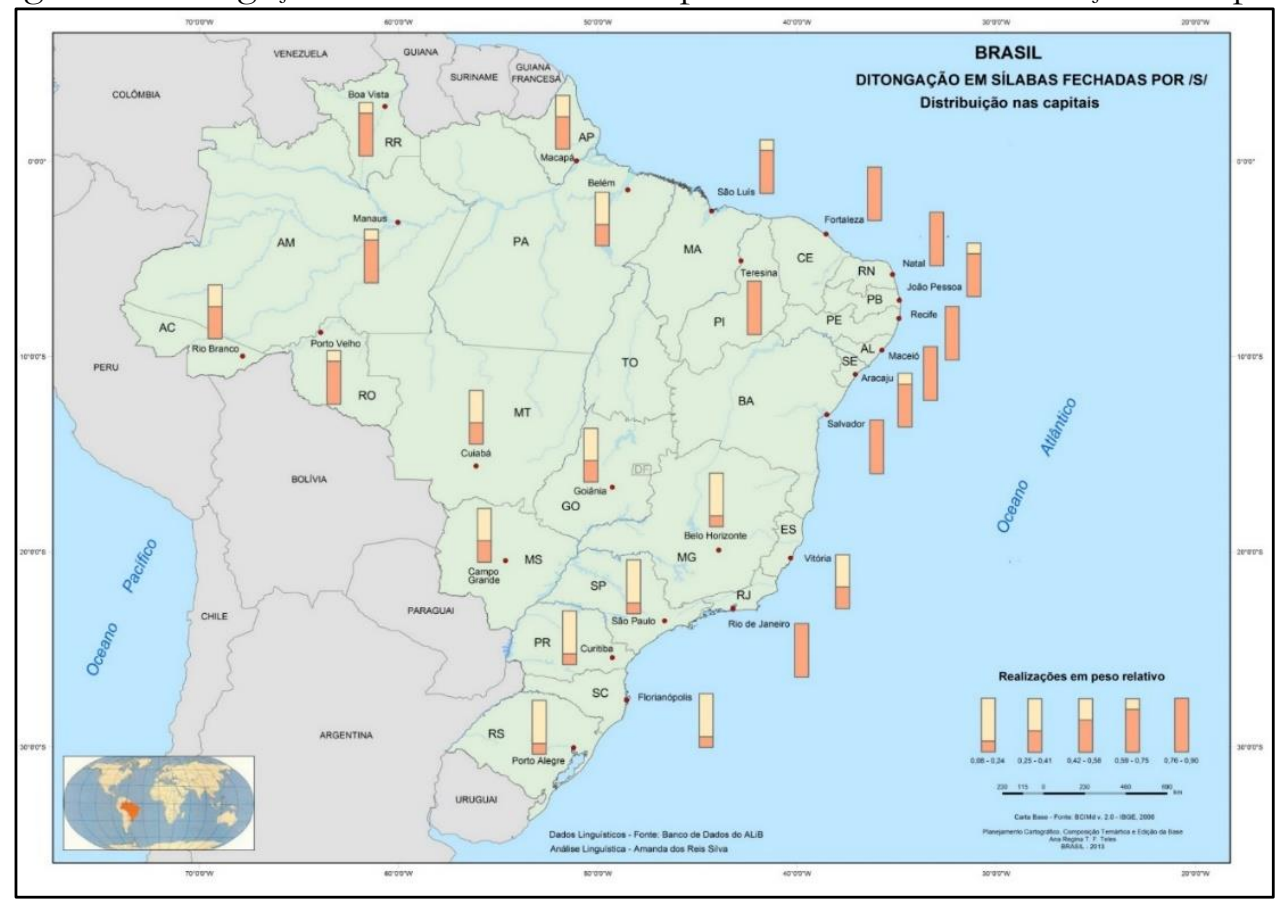

Fonte: Silva (2014).

Ainda que não se possa alegar uma divisão dialetal, com base em tal estudo, haja vista o fato de se limitar às capitais estaduais, foi notada certa oposição entre as localidades dos eixos Norte e Sul do país.

A observação da distribuição dialetal, em consonância com outros aspectos sobretudo, linguísticos, como a extensão dos vocábulos e a qualidade da vogal diante de $<\mathrm{S}>-$, possibilitou fazer inferências acerca da situação do fenômeno no Brasil, que parece ser um traço típico das capitais nordestinas, com formação mais antiga e que passaram por intensos processos de contato entre povos e línguas. Dessas áreas, parece ter se espraiado para outras, ao Norte, onde se encontra restrita a contextos linguísticos específicos, nas capitais do Centro-Oeste, Sudeste e Sul do Brasil.

Assim, na tese Ditongação diante de $<S>$ na Babia: diferenciação dialetal e variação fonéticofonológica, dentre outras questões, foi investigado como se comportavam as cidades no entorno geográfico imediato de Salvador, considerando que o processo de difusão da língua portuguesa na Bahia reflete, em boa medida, os caminhos assumidos pela língua no Brasil. O estudo que ora se apresenta é, assim, um recorte dessa tese, abordando aquilo que se refere especificamente à diferenciação dialetal.

No intuito de melhor direcionar a leitura deste texto, na seção seguinte, serão apresentadas, brevemente, questões sobre a área investigada, a dialetologia baiana e o Projeto ALiB. Depois, serão expostos os aspectos metodológicos adotados para as análises, que serão vistas em seguida. Por fim, são tecidas as considerações finais e expostas as referências. 


\section{A DIALETOLOGIA NA BAHIA E O PROJETO ALiB}

A Dialetologia é a área que se ocupa, prioritariamente, da observação dos usos linguísticos concretos no eixo espacial. No intuito de melhor evidenciar a distribuição espacial das variantes que coleta, registra e analisa, essa disciplina tem como método primordial a Geolinguística, que se refere ao tratamento e apresentação sistemáticos da diversidade por meio de mapas temáticos.

No Brasil, os primeiros testemunhos sobre a realidade dialetal são datados do século XIX. Porém, apenas entre as décadas de 1950 e 1960, começa a ser empregado o método da Geolinguística, com a feitura e publicação do Atlas prévio dos falares baianos (APFB) (ROSSI, 1963).

O Estado da Bahia é a maior unidade federativa do Nordeste brasileiro e a quinta do Brasil. Sua população, segundo o último censo, realizado em 2010, era composta de 14.016.906 indivíduos. Sua história, de modo geral, remonta ao ano de 1500, quando da chegada das primeiras esquadras portuguesas ao seu litoral sul e, à volta de 1530, com a instalação dos portugueses em Salvador e a definição do primeiro governo geral brasileiro.

Diante de séculos de história, quilômetros de extensão - para onde a língua portuguesa foi transplantada em momentos diversos - e milhares de habitantes, dotados de vivências sociais e culturais múltiplas, é inegável a necessidade de compreender o quão diverso é o português falado em áreas baianas. E, mais ainda, é importante explorar as feições dessa diversidade.

Os estudos dialetais acerca do português falado na Bahia prosseguem, hoje, a partir de investigações realizadas nas diferentes universidades do Estado. Dentre as iniciativas em curso, destaca-se o Projeto ALiB, cujos estudos começam a adentrar o conhecimento da realidade do interior do Estado e se voltam a diferentes aspectos da língua falada. Exemplificam esses trabalhos, além da tese de Silva (2018), sobre a ditongação diante de $<$ S $>$, a dissertação de Ribeiro (2018), sobre a palatalização das oclusivas dento-alveolares diante de /i/, e a tese de Santana (2017), que se volta ao vocabulário dialetal baiano.

Quanto ao tratamento geolinguístico dos dados, os trabalhos que se pautam no corpus do ALiB e se propõem a realizar esse tipo de análise e exposição procuram alinhar os conhecimentos da Linguística e da Cartografia, havendo cuidado com as informações geográficas, as formas de apresentação dos resultados, a elaboração das legendas etc. Como informam Teles e Ribeiro (2014), o ALiB se diferencia dos atlas outrora publicados no Brasil tanto pela dimensão espacial abrangida (um país) quanto pelos recursos disponíveis e adotados. Não se trata de um conjunto de cartogramas, mas de mapas (ou cartas) elaborados sobre uma base cartográfica oficial (a do Instituto Brasileiro de Geografia e Estatística, IBGE), passível de utilização em um Sistema de Informações Geográficas (SIG). Além de vantagens pertinentes à precisão com que as localidades são dispostas e identificadas nos mapas, em termos de sua localização geográfica (latitude e longitude), 
a observação à Cartografia oficial permitirá que, em qualquer época, a partir da edição desse novo mapa, qualquer localidade ou acidente físico possa ser identificado, e a ela (ou ele) agregadas informações de cunho geográfico, histórico e socioeconômico atualizadas. (TELES; RIBEIRO, 2014, p. 120)

Assim, ao fazer Geolinguística, os pesquisadores do ALiB fornecem não somente dados de fala atualizados mas os situam, precisamente, nas áreas estudadas, permitindo uma adequada correlação entre os achados referentes à língua portuguesa na Bahia e no Brasil e informações de cunho geográfico, histórico e socioeconômico das localidades estudadas. Essa possibilidade se estabelece, pois, na medida em que se trabalha com dados georreferenciados e é facultado o acesso a bancos de dados com informações pertinentes às localidades e aos papéis desempenhados por eventuais acidentes geográficos que interfiram na realidade linguística das áreas.

Este artigo, desse modo, configura-se como uma pequena contribuição aos estudos geolinguísticos sobre o português falado na Bahia, oferecendo dados sistematizados sobre a ditongação diante de $<\mathrm{S}>$ e os interpretando, na medida do possível, à luz de informações históricas, sociais e geográficas.

\section{ASPECTOS METODOLÓGICOS}

As análises efetuadas com base no corpus do ALiB proporcionam um conhecimento dos falares da Bahia, à luz de dados atualizados, cuja recolha sistemática, in loco, deu-se entre os anos de 2003 e 2009, em 22 cidades. São elas, em ordem conforme a definição da rede de pontos do ALiB (de Norte a Sul, de Leste a Oeste): Juazeiro, Jeremoabo, Euclides da Cunha, Barra, Irecê, Jacobina, Barreiras, Alagoinhas, Seabra, Itaberaba, Santo Amaro, Santana, Salvador, Valença, Jequié, Caetité, Carinhanha, Vitória da Conquista, Ilhéus, Itapetinga, Santa Cruz Cabrália e Caravelas.

As observações são pautadas na fala de informantes nativos das referidas localidades e estratificados segundo o sexo (homens e mulheres) e a faixa etária (faixa I, de 18 a 30 anos; faixa II, de 50 a 65 anos), tendo sido ouvidos, portanto, quatro indivíduos em cada cidade. Todos os informantes possuem escolaridade de nível fundamental. Para Salvador, foram incluídos mais quatro sujeitos, com escolaridade universitária. São, assim, estudos que podem refletir a fala de 92 indivíduos da Bahia. Neste estudo, porém, são considerados apenas os informantes de nível fundamental e foi excluído o informante homem, de primeira faixa etária, de Juazeiro, por problemas pertinentes à digitalização do inquérito.

Como foi informado nos trechos iniciais deste artigo, foram feitas duas análises diferentes e complementares, de modo que se tenha uma visão mais pormenorizada da distribuição das realizações ditongadas diante de $<\mathrm{S}>$. A primeira delas baseou-se em respostas obtidas a propósito de seis perguntas do Questionário Fonético-Fonológico (QFF) do Projeto ALiB (COMITÊ NACIONAL, 2001), especificamente voltadas à observação da ditongação diante de $<\mathrm{S}>$.

Foi percebida a necessidade dessa primeira verificação, pois o QFF se volta à obtenção de vocábulos específicos, para a averiguação de determinados fenômenos 
fonético-fonológicos. Destarte, há certas palavras e, portanto, estruturas fonológicas, que se repetem no corpus, de modo significativo.

Dentre as 159 questões que constituem o QFF, ganham destaque, aqui, as seis já referidas, que se direcionam ao fenômeno em estudo:

- QFF009 - LUZ

Quando está escuro é porque faltou o quê? [Quando falta energia é que ficou sem ?]

- QFF021 - ARROZ

... o que se come no almoço, uns grãozinhos brancos que podem acompanhar o feijão, a carne?

- QFF063 - TRÊS

O que é que vem depois do dois?

- QFF064 - DEZ

$\mathrm{O}$ que é que vem depois do nove?

- QFF137 - VOZ

Uma pessoa que canta bem, se diz que ela tem uma boa

- QFF155 - PAZ

Se a pessoa não quer ser incomodada, a pessoa diz: Me deixe em

Como se vê, essas perguntas têm como alvo monossílabos tônicos ('luz', 'três', 'dez', 'paz' e 'voz') e um dissílabo oxítono ('arroz'). Foi feita, então, a observação desses vocábulos, de modo a averiguar a criação de possíveis vieses, uma vez que, quando foram verificados os levantamentos feitos, a partir dos inquéritos de cada um dos informantes, foi percebido que esses itens ocorriam em praticamente todas as entrevistas. Foram organizadas, assim, em tabelas, as realizações fonéticas das primeiras respostas dos informantes a essas questões. Em seguida, foram contados, manualmente, as ocorrências de ditongação, as ausências de ditongação diante de $<\mathrm{S}>$ e os casos de respostas não obtidas. Diante dos valores, calcularam-se percentuais, com relação à totalidade de informantes.

Para a confecção das cartas linguísticas, foi utilizada a base cartográfica do Estado da Bahia, definida pela Comissão de Informatização e Cartografia do Projeto ALiB e elaborada pela Profa. Dra. Ana Regina Torres Ferreira Teles (UFBA / Escola Politécnica). Foram considerados os totais de casos de ditongação em cada localidade, para cada vocábulo, tendo sido produzida uma carta para cada um deles. $\mathrm{Na}$ seção seguinte, serão comentados os resultados para a distribuição das variantes ditongadas em cada uma das situações.

Além dos seis vocábulos controlados sistematicamente pelo QFF, realizou-se uma averiguação dos condicionamentos para a ditongação diante de $<\mathrm{S}>$ com base em elocuções dos informantes, obtidas a propósito das gravações das demais perguntas do QFF e do Questionário Semântico-Lexical (QSL). Nesse momento, além das respostas às perguntas, foram tomadas para análise ocorrências de vogais em sílabas fechadas por $<\mathrm{S}>$ 
referentes, também, à fala espontânea. Desse modo, foram registrados dados como os que se exemplificam a seguir:

(i) INQ. - Quando se quer saber uma coisa, se vai...?

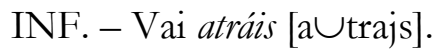

[Ocorrência obtida da fala do homem, de segunda faixa etária, natural de Alagoinhas, a propósito da questão 152 do QFF, que tem como alvo o vocábulo 'perguntar'.]

(ii) INF. - Quem habitô, na época, que nós [Unos] compramo... Cabei de dizê, que nós chegô em cinquenta e ôtcho, aí nós [Unos] trabalhô na ôtra rua, que é José Bonifácio. Aí nóis [Unojs] mudô pra cá, que é marechal, que é uma travessa. Compreendendo, né? Daqui até o rio era uma mata que plantava arroz. [a Ufojs] e tudo e coisa, né?

[Dados coletados dos comentários espontâneos do informante da segunda faixa etária, natural de Barreiras, a propósito da questão 001 do QFF, que visa à obtenção do vocábulo 'casa'.]

(iii) INF. - É uma carambola mermo que a gente faiz. [ $\cup$ faj] $\ldots .$.

[Registro obtido a propósito de comentário do informante de segunda faixa etária, de Santo Amaro, a respeito da pergunta 159 do QSL, referente a um tipo de brinquedo feito com papel, que se empina no vento, sem varetas ('pipa'/'arraia').]

Não foram considerados casos em que a vogal ocupante do núcleo silábico era realizada foneticamente como vogal alta anterior [i], dada a similaridade fonética desta com a semivogal possivelmente formada no processo de ditongação. Além dessas, foram descartadas também: (i) vogais nasais ou nasalizadas, uma vez que há tendência à sua ditongação em posição tônica (CÂMARA JR., 2008 [1953]); (ii) nomes próprios, por sua pouca recorrência na fala cotidiana; e (iii) clíticos, dado o fato de serem elementos cujo status fonológico é instável (BISOL, 2000). Para cada um dos informantes, foi definido o levantamento de até três ocorrências do mesmo vocábulo, com igual realização fonética, para evitar possíveis vieses.

Foram contabilizadas, ao todo, 5001 ocorrências de sílabas fechadas por $<\mathrm{S}>$, distribuídas entre casos de ditongação $(1254,25 \%$ dos dados) e ausência de ditongação (3747, 75\% dos dados). Haja vista se tratar de uma regra variável, foram feitas rodadas quantitativas por meio do GoldV arb 2001, para que se averiguassem os condicionamentos linguísticos e extralinguísticos para a ditongação diante de $<\mathrm{S}>$. Em uma primeira rodada, da qual se extraem os resultados apresentados neste artigo, foram tomados os seguintes grupos de fatores, de acordo com a ordem de seleção do programa:

(1) número de sílabas da palavra fonológica;

(2) qualidade da vogal no núcleo silábico; 
(3) posição da sílaba na palavra fonológica;

(4) tonicidade da sílaba fechada por $<\mathrm{S}>$;

(5) distribuição diatópica;

(6) realização fonética da consoante em coda silábica;

(7) posição da consoante com relação à palavra fonológica;

(8) sexo do informante.

Neste trabalho, então, serão apresentados os valores obtidos para a distribuição diatópica da ditongação diante de $<\mathrm{S}>$, os quais serão comentados e, em seguida, expostos em uma carta linguística. Procura-se averiguar, assim, por meio das duas análises, como se distribuem as variantes ditongadas no espaço baiano e tecer considerações, ainda que gerais, acerca de possíveis condições geográficas, sociais e históricas para a distribuição encontrada.

\section{RESULTADOS}

Ao observar o cômputo geral das ocorrências de ditongação para os seis vocábulos controlados no QFF, com base nos dados dos 87 informantes baianos, é perceptível que os vocábulos 'luz', 'arroz', 'voz' e 'paz', nesta ordem, apresentaram, no panorama geral, frequências um pouco mais baixas de ditongação do que 'três' e 'dez', que tiveram suas vogais ditongadas de modo mais expressivo ${ }^{6}$, como é apresentado na Figura 3.

Fig.2 - Frequência de ditongação em monossílabos tônicos e oxítono controlados no QFF

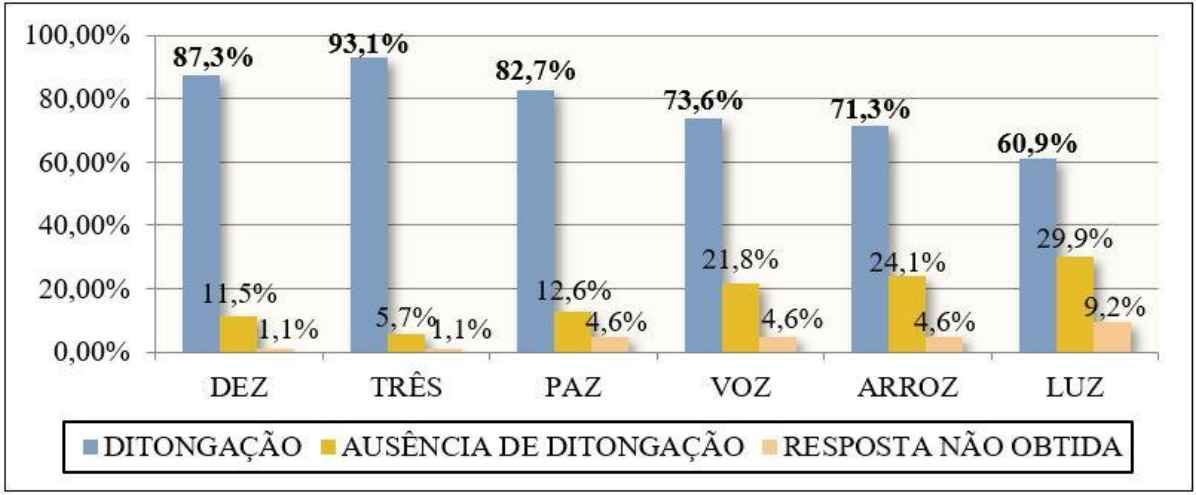

No caso do vocábulo 'três', cujo índice de ditongação é o mais elevado, é destaque a sua relação com o vocábulo 'dois', que apresenta uma estrutura semelhante (monossílabo tônico) e um ditongo fonológico diante de $<\mathrm{S}>$. A presença do 'dois' na pergunta que serve de meio para a obtenção do item merece ser pontuada, pois a presença

${ }^{6}$ Como foi dito, para a obtenção desses valores, foi vista apenas a primeira resposta do informante à pergunta em questão. Portanto há sempre, entre ocorrências de ditongação, não ditongação e respostas não obtidas, um total de 87. 


\section{Revista das Letras}

dessa realização ditongada, na fala do inquiridor, pode atuar como uma espécie de gatilho à ditongação da vogal em 'três'.

E relevante observar que, na medida em que há um maior grau de recuo na articulação das vogais constituintes dos núcleos das sílabas fechadas por $\langle\mathrm{S}\rangle$, nesses vocábulos, o percentual de ditongação nos mesmos é menor, como é exemplar o caso da vogal alta posterior [u], em 'luz'.

Será apresentado, adiante, por meio de cartas linguísticas, o que ocorre nas cidades estudadas.

Fig. 3 - Ditongação diante de $<\mathrm{S}>$ na Bahia: realizações do vocábulo três em respostas ao QFF 063

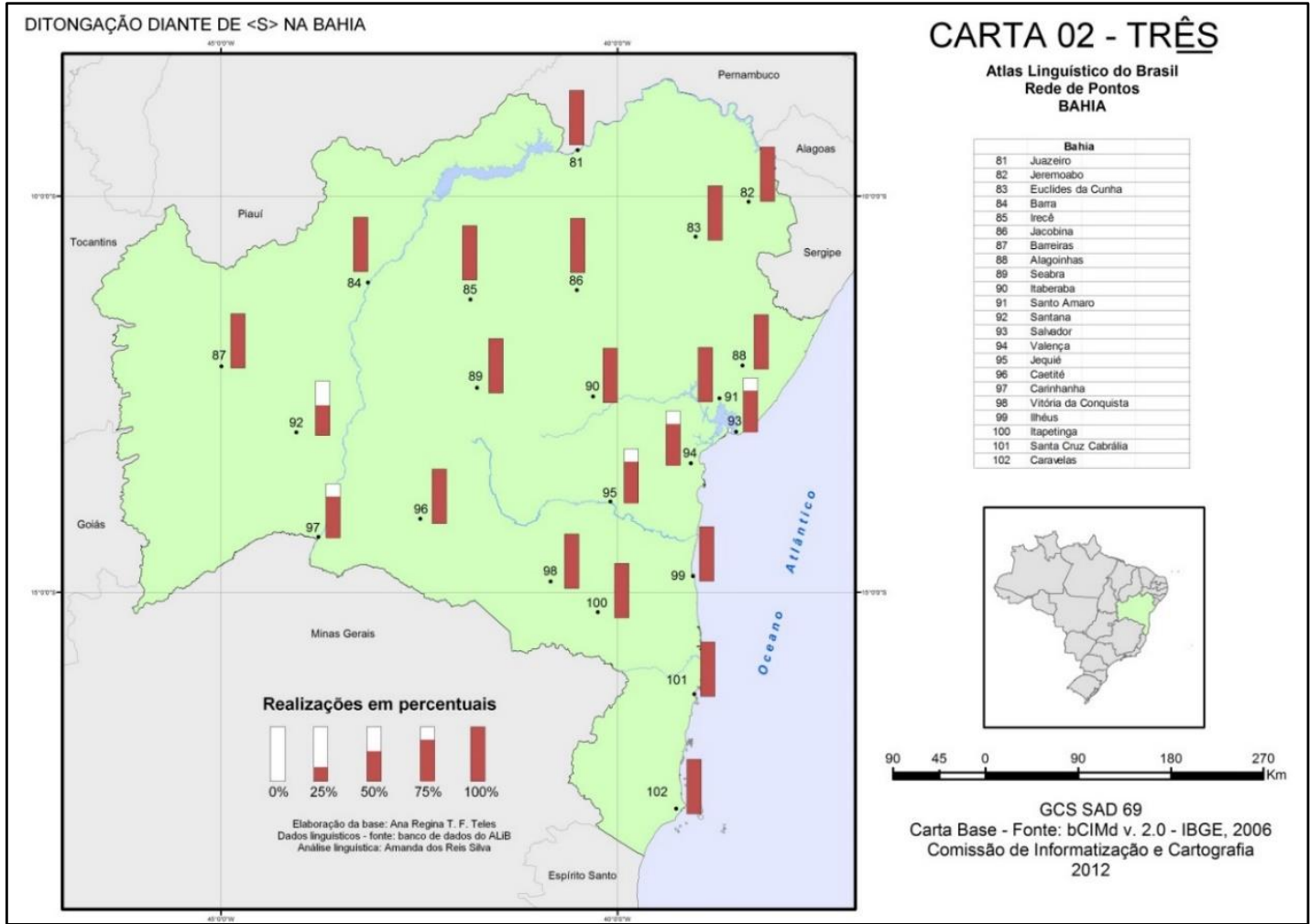

Em observação à Figura 3, a ditongação de [e] no vocábulo observado é bastante difundida dentre as localidades baianas estudadas. Somente os informantes do ponto 92 (Santana) demonstram uma menor tendência à ditongação vocálica nesse contexto $(50 \%$ das realizações). Nos pontos 93 (Salvador), 94 (Valença), 95 (Jequié), 97 (Carinhanha) e 100 (Itapetinga), também não há ditongação nas respostas de todos os informantes (75\% das respostas). Todavia, em alguns casos, as vogais não ditongadas podem refletir realizações fortuitas ou idioletais, diante do comportamento assumido pelos informantes no decorrer dos inquéritos. 


\section{Revista \\ A Cor das Letras}

Fig. 4 - Ditongação diante de $<\mathrm{S}>$ na Bahia: realizações do vocábulo dę em respostas ao QFF 064

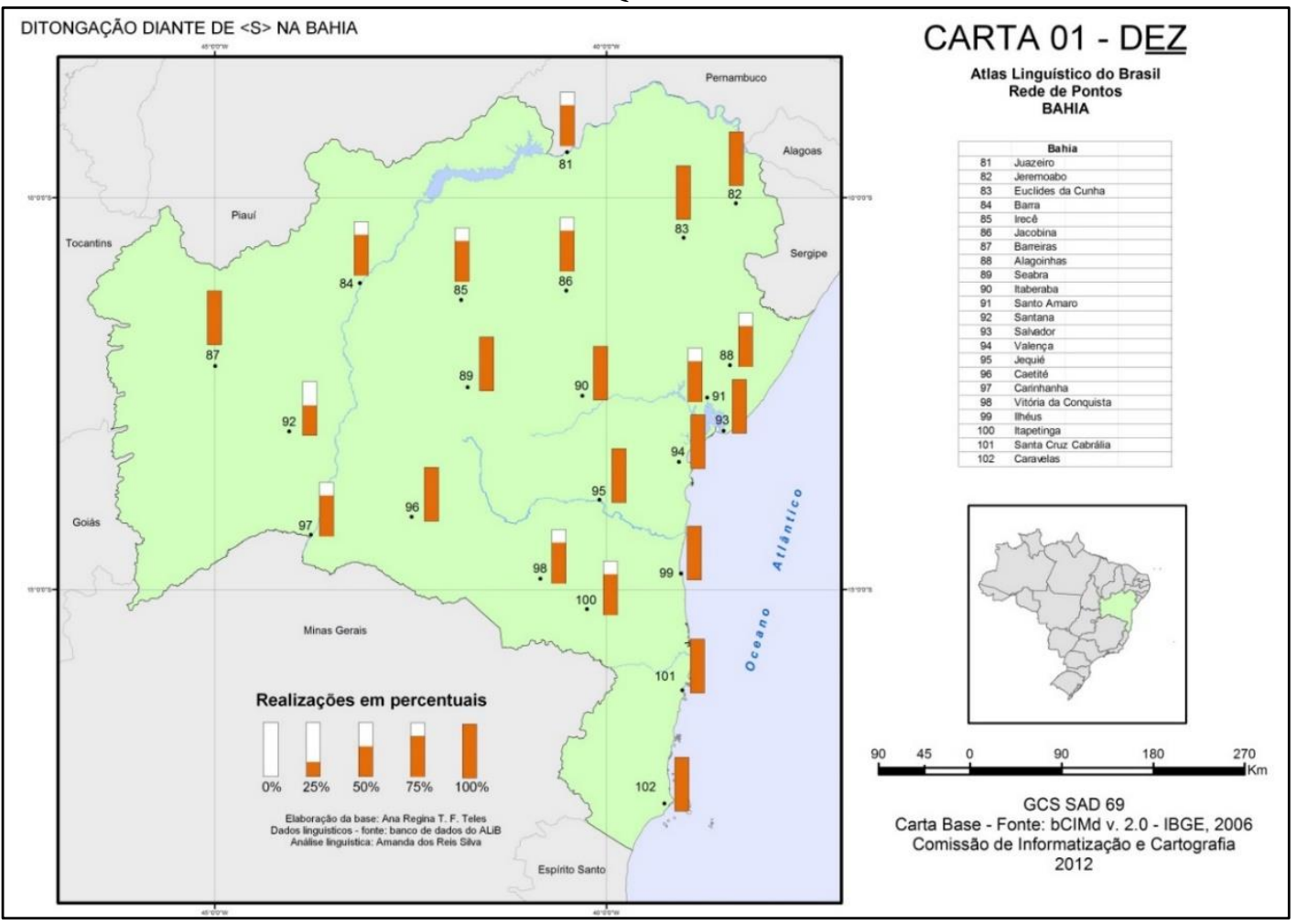

De acordo com o que se percebe na Figura 4, a ditongação da vogal [E], no vocábulo dez, é praticamente geral nas 22 cidades estudadas, quando são vistas as respostas dos informantes à pergunta especificamente dirigida a esse item.

Mais uma vez, apenas no ponto 92 (Santana) a taxa de realizações ditongadas cai para 50\% das respostas possíveis. Nos pontos 81 (Juazeiro), 84 (Barra), 85 (Irecê), 86 (Jacobina), 97 (Carinhanha), 98 (Vitória da Conquista) e 100 (Itapetinga), essa taxa se eleva para $75 \%$ das ocorrências. Nas demais cidades, todos os informantes forneceram como resposta a forma [ $\cup \mathrm{d} \varepsilon j \mathrm{~s}]$, ditongada.

Fig. 5 - Ditongação diante de $<\mathrm{S}>$ na Bahia: realizações do vocábulo paz em respostas ao QFF 155 

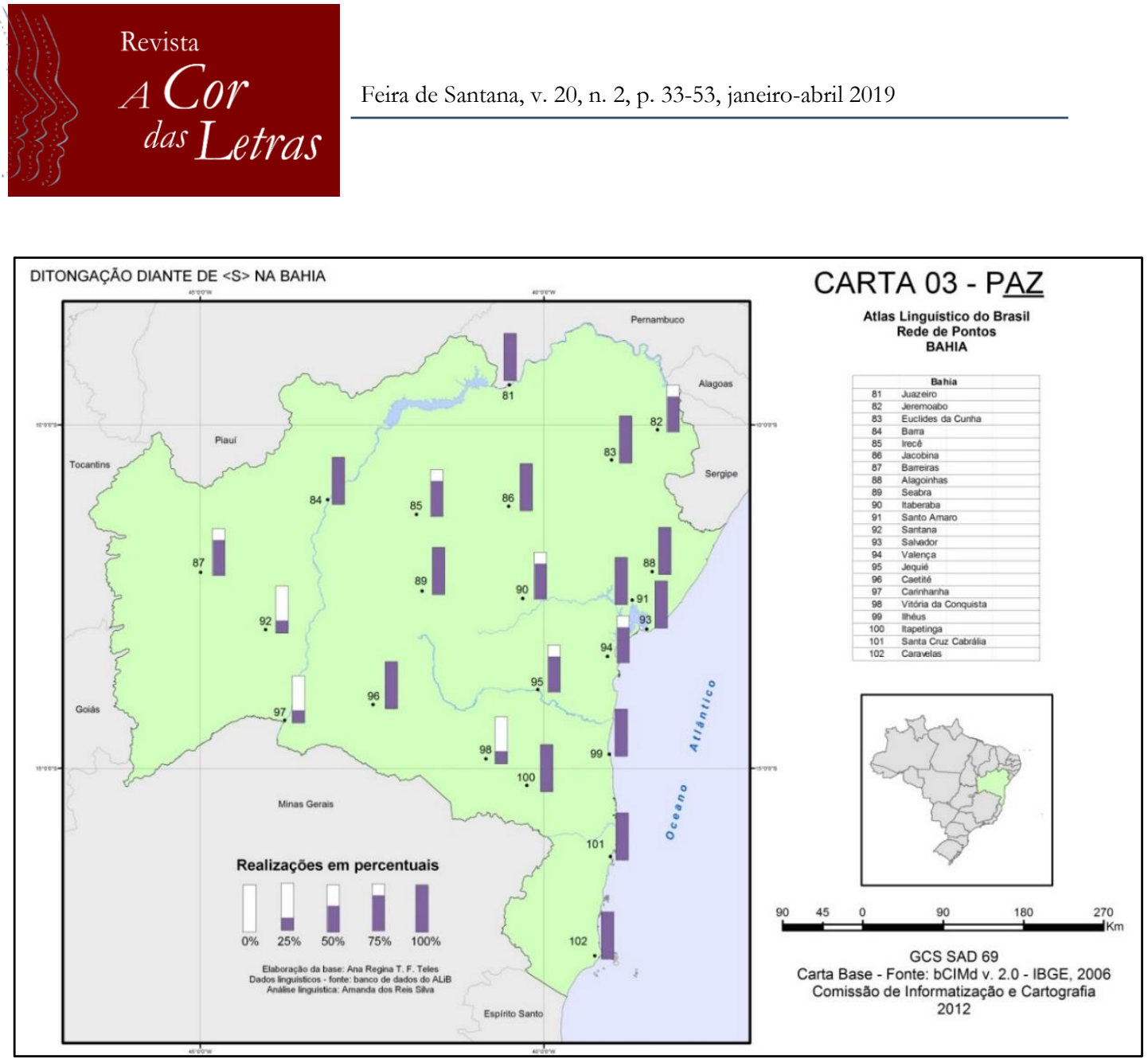

No contexto geral, diante do disposto na Figura 5, a ditongação da vogal baixa central [a] em pazé um pouco menos expressiva do que nos dois casos anteriores.

Nos pontos 92 (Santana), 97 (Carinhanha) e 98 (Vitória da Conquista), só há ditongação vocálica na fala de um dos informantes ( $25 \%$ das ocorrências). Em Jeremoabo (82), Irecê (85), Barreiras (87), Itaberaba (90), Valença (94) e Jequié (95), o percentual sobe para $75 \%$ das ocorrências. Nas demais cidades, há ditongação na fala de todos os informantes.

Fig. 6 - Ditongação diante de $<\mathrm{S}>$ na Bahia: realizações do vocábulo arroz em respostas ao QFF 021 


\section{das Letras}

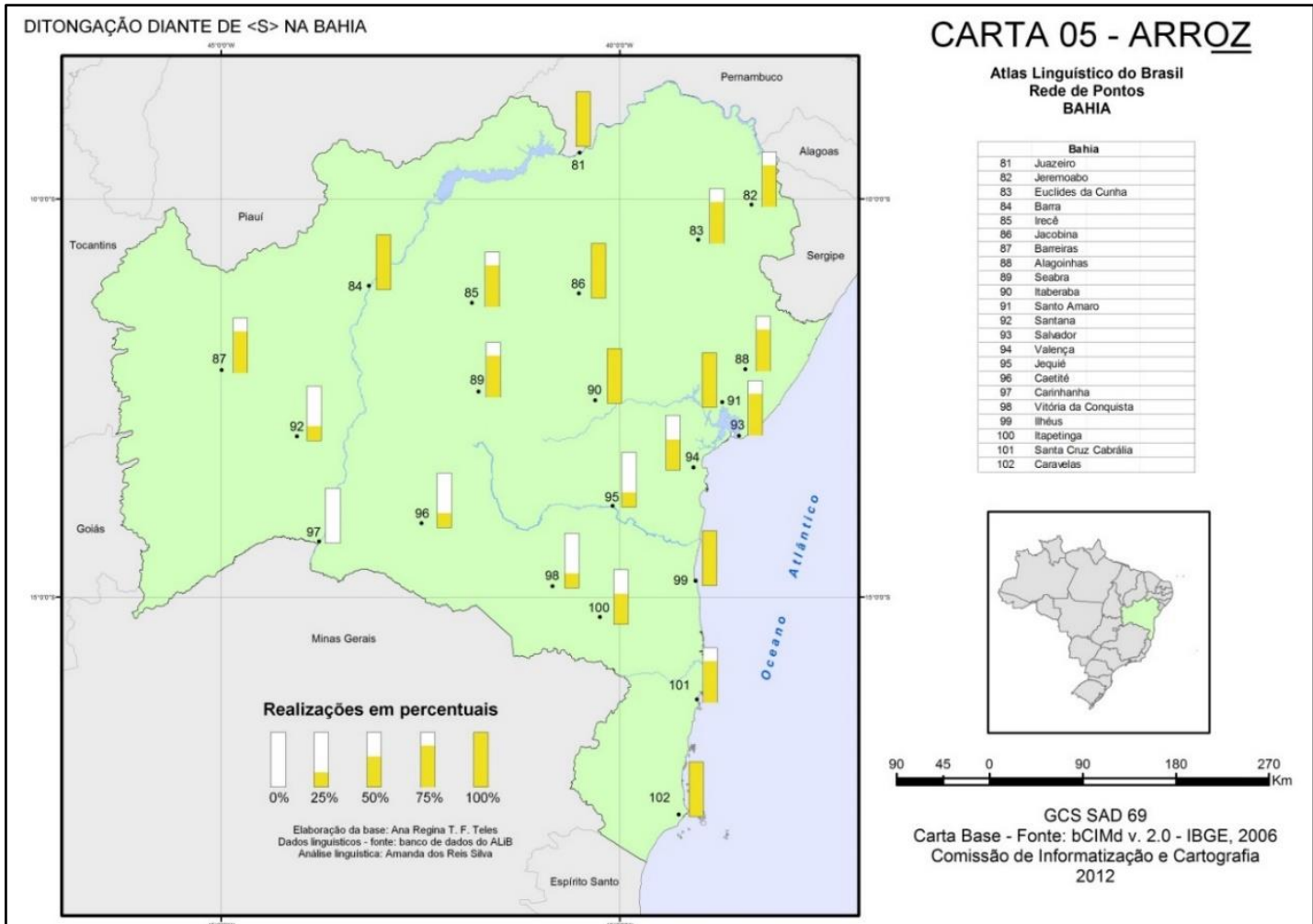

Para a vogal média-alta posterior [o], no vocábulo arroz, as áreas de vogais não ditongadas são percebidas com certa clareza, como demonstra a Figura 6.

Em Carinhanha (97), a ditongação é nula ( $0 \%$ das ocorrências). Apenas um informante (25\% das ocorrências) produz vogal ditongada em Santana (92), Jequié (95), Caetité (96) e Vitória da Conquista (98). Em Valença (94), a frequência sobe para 50\% dos casos.

Dentre as cidades que apresentam $75 \%$ de frequência de ditongação, nesse contexto, estão Jeremoabo (82), Euclides da Cunha (83), Irecê (85), Barreiras (87), Alagoinhas (88), Seabra (89), Salvador (93) e Santa Cruz Cabrália (101). Deve ser destacado que aí estão cidades cuja tendência era a totalidade de vogais ditongadas, nos contextos dos vocábulos três, dez e paz, como Santa Cruz Cabrália, Salvador e Alagoinhas. Nas demais (Juazeiro, Barra, Jacobina, Itaberaba, Santo Amaro, Ilhéus e Caravelas), a frequência é de 100\%.

Fig. 7 - Ditongação diante de $<\mathrm{S}>$ na Bahia: realizações do vocábulo voz em respostas ao QFF 137 

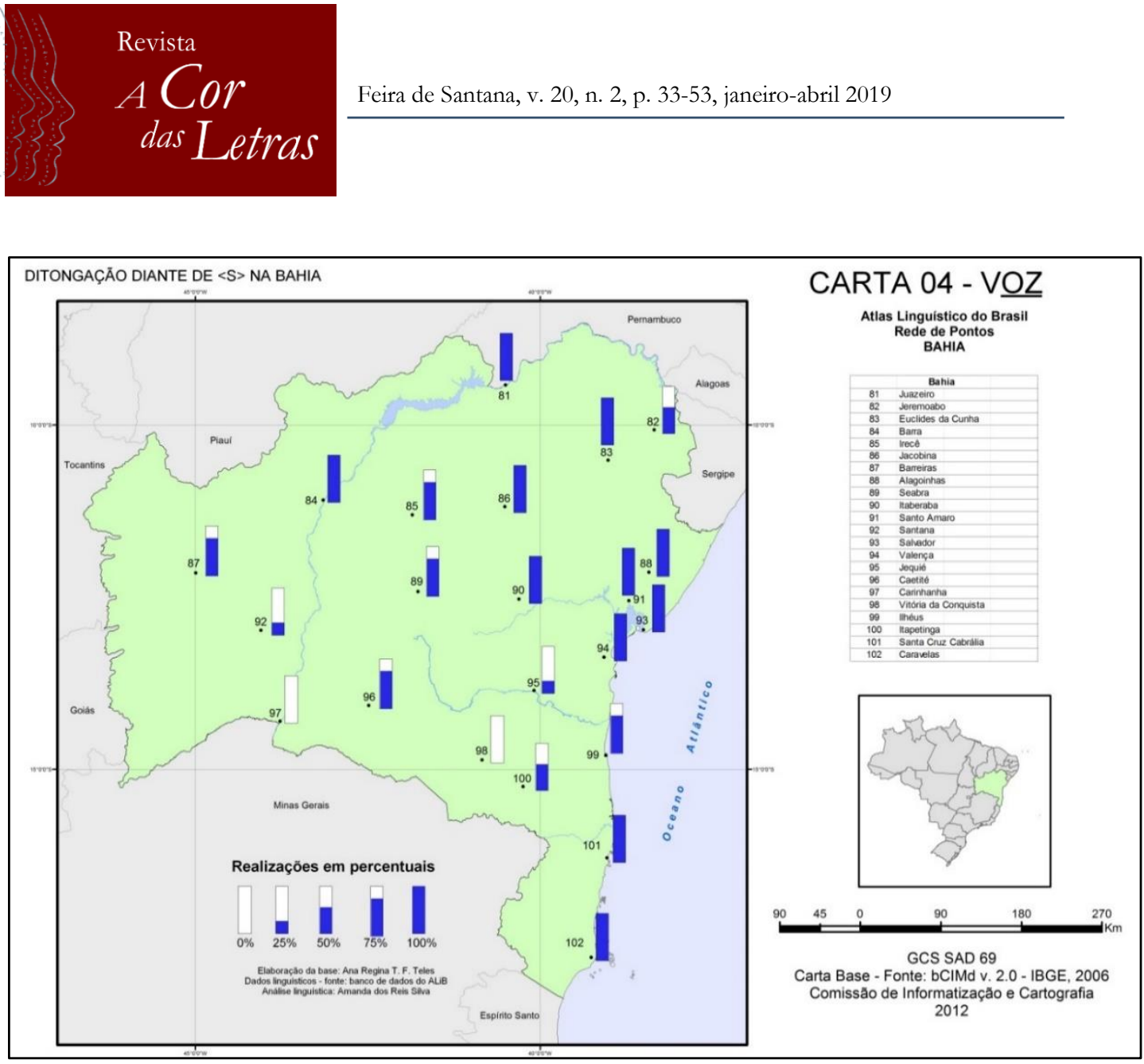

O caso da vogal média-baixa posterior [ગ] reforça as tendências já observadas para as áreas estudadas. As cidades que tendem à não ditongação das vogais diante de $<\mathrm{S}>$, nos outros contextos vocabulares, nesse caso, têm tal quadro visto de modo expressivo na análise do vocábulo voz, conforme a Figura 7.

Nos pontos 97 e 98, Carinhanha e Vitória da Conquista, respectivamente, não há ditongação vocálica na fala de nenhum informante. Em Santana (92) e Jequié (95), a taxa de ditongação é de apenas $25 \%$ das ocorrências. Em Jeremoabo, ponto 82, o valor se eleva para 50\% dos casos. O mesmo ocorre em Itapetinga, ponto 100. Em Irecê (85), Barreiras (87), Seabra (89) e Ilhéus (99), o valor é de 75\% das ocorrências. Nas demais cidades, há ditongação em todos os casos.

Fig. 8 - Ditongação diante de $<\mathrm{S}>$ na Bahia: realizações do vocábulo luz em respostas ao QFF 009 


\section{das Letras}

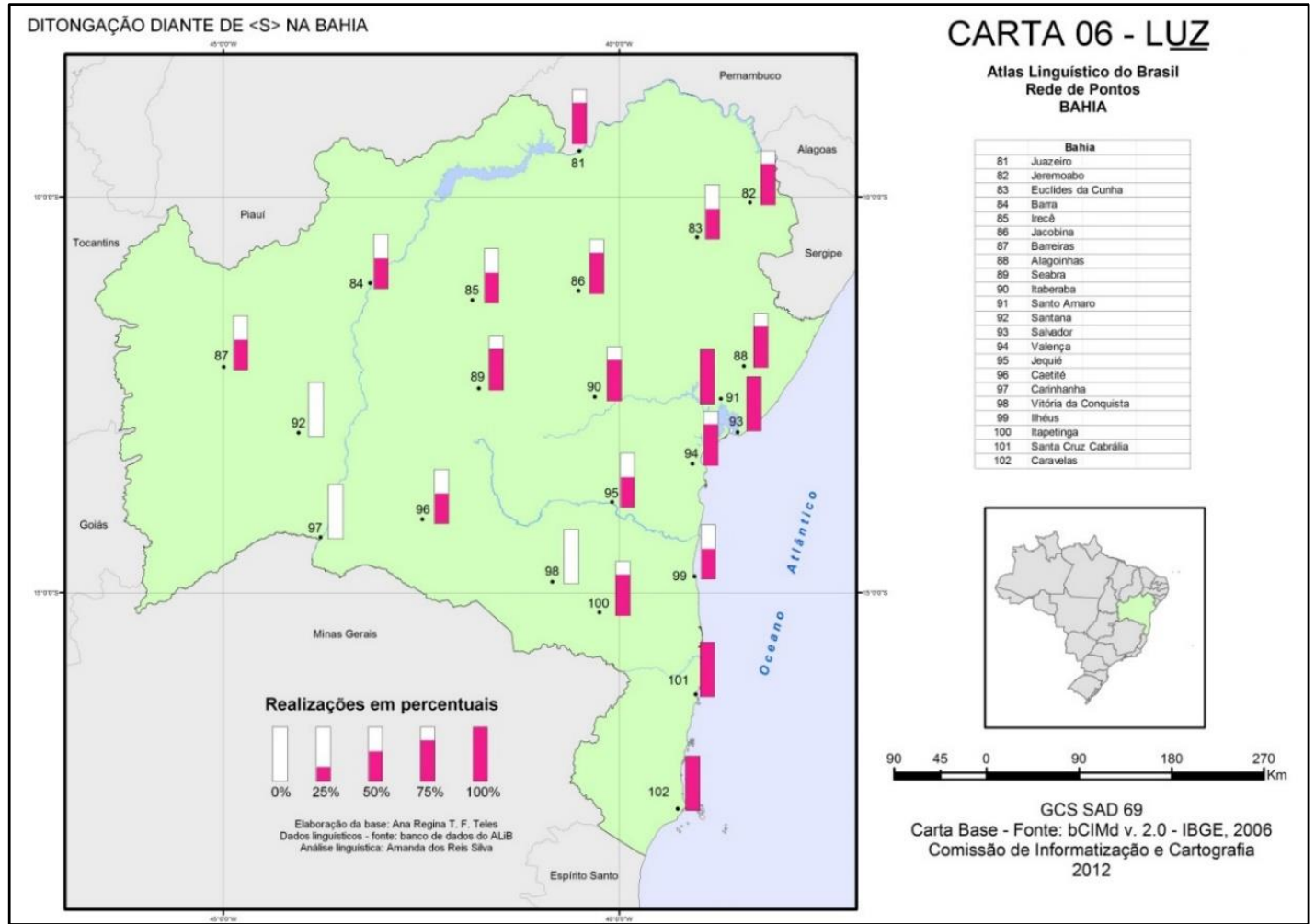

O panorama demonstrado na Figura 8 revela que a ditongação da vogal alta posterior [u], no monossílabo tônico luq, é ainda menos expressiva do que o que ocorre com as vogais posteriores anteriormente apresentadas. Quanto às localidades, os dados apresentados reiteram as tendências já vistas até aqui.

Em Santana (92), Carinhanha (97) e Vitória da Conquista (98), não há registros de ditongação no contexto desse vocábulo. Metade dos informantes (50\% das ocorrências) ditongam a vogal de 'luz' em Euclides da Cunha (83), Barra (84), Irecê (85), Barreiras (87), Jequié (95), Caetité (96) e Ilhéus (99). A frequência sobe para 75\% em Juazeiro (81), Jeremoabo (82), Jacobina (86), Alagoinhas (88), Seabra (89), Itaberaba (90), Valença (94) e Itapetinga (100). Apenas em Santo Amaro (91), Salvador (93), Santa Cruz Cabrália (101) e Caravelas (102) há ditongação na resposta de todos os informantes.

Dessa observação particular, é notável que há localidades que aparentam uma menor possibilidade de ditongação diante de $<\mathrm{S}>$ do que outras, enquanto há algumas em que os informantes oscilam quanto ao fenômeno. Nestas, provavelmente, as vogais ditongadas estão restritas a contextos específicos. Quanto às vogais, genericamente, é visto que, quanto mais posteriores e fechadas, menor tendência à ditongação.

A partir daqui, são expostos os resultados obtidos para a distribuição diatópica das vogais ditongadas diante de $<\mathrm{S}>$, com base na análise quantitativa, que se pauta nos valores obtidos por meio do GoldV arb 2001. Mediante esses resultados, procura-se identificar áreas que se caracterizam pela maior possibilidade de vogais ditongadas e aquelas nas quais é perceptível uma maior proeminência de sílabas sem ditongação 
vocálica. Assim, busca-se confirmar ou refutar as tendências observadas a partir dos seis vocábulos do QFF, verificando em que medida essas cidades podem ser agrupadas quanto a esse fenômeno, de modo a ter indícios para futuras divisões dialetais.

Não obstante, tomando por base o fato de que este estudo se debruça sobre os dados da Bahia, em razão do comportamento peculiar de Salvador perante as demais capitais brasileiras (SILVA, 2014), são averiguadas as cidades que se aproximam desse perfil, procurando observar de que maneira aspectos sócio-históricos e culturais podem trazer indícios acerca da existência desse traço em certas normas do PB. Na Tabela 1, são expostos os resultados obtidos para essa variável.

Tabela 1: A ditongação diante de $<\mathrm{S}>$ em cidades baianas, segundo a distribuição diatópica: dados do Projeto ALiB

\begin{tabular}{|c|c|c|c|}
\hline LOCALIDADE & APLIC. / TOTAL & $\%$ & $\begin{array}{c}\text { PESO } \\
\text { RELATIVO }\end{array}$ \\
\hline Juazeiro & $45 / 177$ & 25 & 0,49 \\
\hline Jeremoabo & $73 / 305$ & 23 & 0,40 \\
\hline Euclides da Cunha & $83 / 298$ & 27 & 0,51 \\
\hline Barra & $47 / 218$ & 21 & 0,41 \\
\hline Irecê & $63 / 249$ & 25 & 0,42 \\
\hline Jacobina & $45 / 152$ & 29 & 0,55 \\
\hline Barreiras & $76 / 287$ & 26 & 0,53 \\
\hline Alagoinhas & $64 / 261$ & 24 & 0,60 \\
\hline Seabra & $55 / 209$ & 26 & 0,58 \\
\hline Itaberaba & $59 / 206$ & 28 & 0,59 \\
\hline Santo Amaro & $54 / 189$ & 28 & 0,83 \\
\hline Santana & $31 / 203$ & 15 & 0,20 \\
\hline Salvador & $71 / 232$ & 30 & 0,86 \\
\hline Valença & $65 / 212$ & 30 & 0,53 \\
\hline Jequié & $33 / 152$ & 21 & 0,47 \\
\hline Caetité & $64 / 227$ & 28 & 0,54 \\
\hline Carinhanha & 39/201 & 19 & 0,23 \\
\hline Vitória da Conquista & $43 / 270$ & 15 & 0,19 \\
\hline Ilhéus & $60 / 261$ & 22 & 0,59 \\
\hline Itapetinga & $35 / 172$ & 20 & 0,37 \\
\hline Santa Cruz Cabrália & $72 / 262$ & 27 & 0,48 \\
\hline Caravelas & $77 / 258$ & 29 & 0,64 \\
\hline
\end{tabular}

Diante dos valores dispostos na Tabela 1, em atenção aos pesos relativos, é visto que as localidades se comportam de modo diferente, havendo desde aquelas em que a ditongação diante de $<\mathrm{S}>$ é amplamente favorecida àquelas em que o fenômeno é bastante restringido. Assim, é possível separá-las em grupos. Identificam-se, nesse sentido, quatro diferentes categorias: 


\section{Revista das Letras}

(1) Cidades baianas em que os pesos relativos pertinentes à ditongação diante de $<$ S $>$ são elevados - Salvador $(0,86)$ e Santo Amaro $(0,83)$;

(2) Cidades baianas que apresentam pesos levemente favoráveis quanto à ditongação diante de $<\mathrm{S}>$ - Caravelas $(0,64)$, Alagoinhas $(0,60)$, Itaberaba $(0,59)$, Ilhéus $(0,59)$ e Seabra $(0,58)$;

(3) Cidades baianas que apresentam pesos próximos à neutralidade - Jacobina $(0,55)$, Caetité $(0,54)$, Valença $(0,53)$, Barreiras $(0,53)$ e Euclides da Cunha $(0,51)$

(4) Cidades baianas que apresentam pesos baixos e, portanto, em que os informantes restringem a ditongação em sílabas fechadas por $<\mathrm{S}\rangle-$ Juazeiro $(0,49)$, Santa Cruz Cabrália $(0,48)$, Jequié $(0,47)$, Irecê $(0,42)$, Barra $(0,41)$, Jeremoabo $(0,40)$, Itapetinga $(0,37)$, Carinhanha $(0,23)$, Santana $(0,20)$ e Vitória da Conquista $(0,19)$.

A partir da Figura 9, é possível evidenciar a distribuição diatópica da ditongação diante de $<\mathrm{S}>$ nas cidades da Bahia, integrantes do corpus do Projeto ALiB, com base nos pesos relativos obtidos.

Fig. 9 - Distribuição diatópica da ditongação diante de $<\mathrm{S}>$ no Estado da Bahia: dados do Projeto ALiB

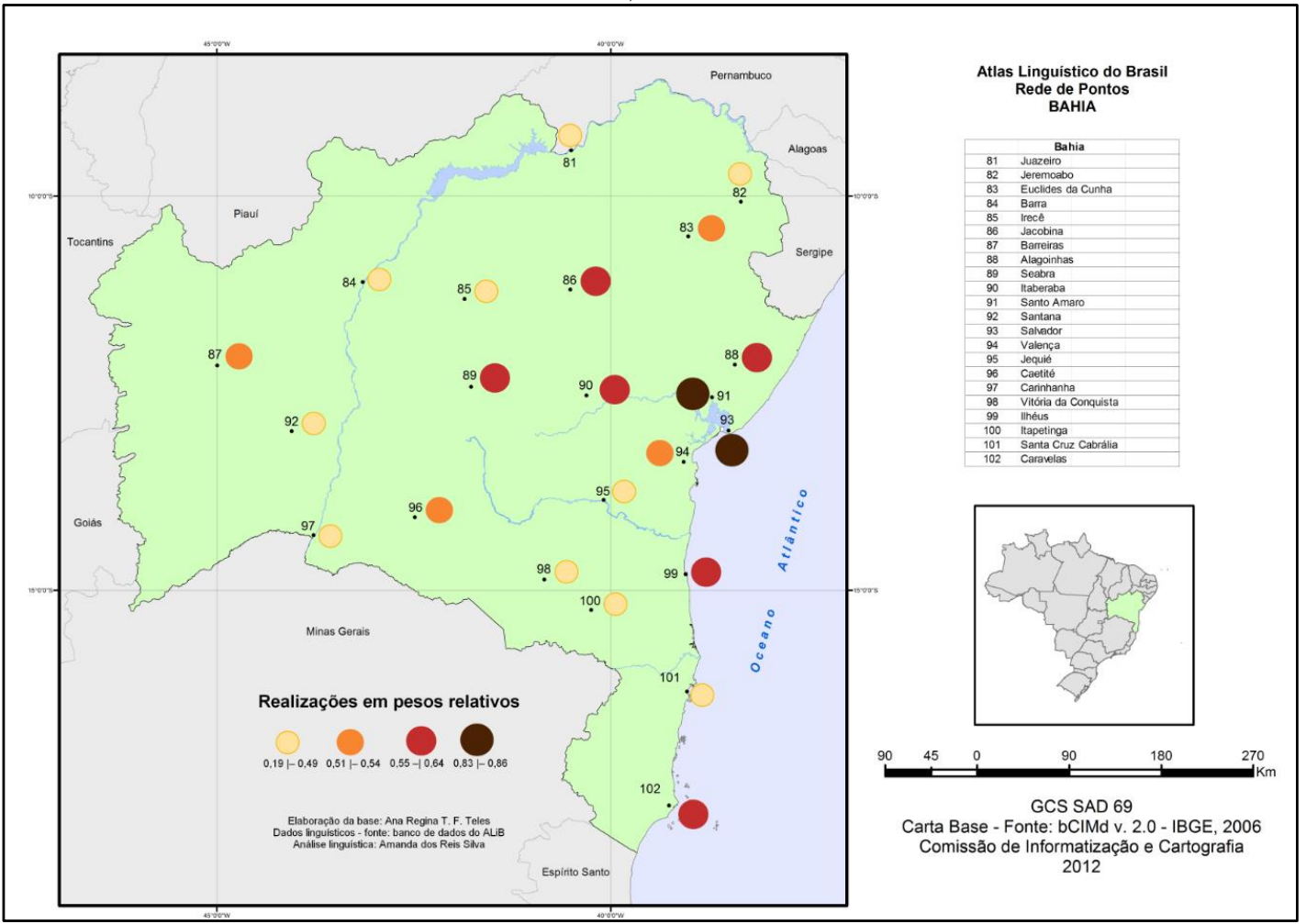


Diante do exposto, percebe-se que duas dentre as 22 cidades consideradas Salvador e Santo Amaro, no Recôncavo Baiano - apresentam pesos altos e mais expressivos com relação à ditongação em sílabas fechadas por $<\mathrm{S}\rangle$. Há ainda o caso de cinco cidades - Caravelas, Alagoinhas, Itaberaba, Ilhéus e Seabra - que apresentam pesos favoráveis à ditongação, porém não tão expressivos quanto as anteriores. Duas dessas cidades, Caravelas $(0,64)$ e Ilhéus $(0,60)$, estão situadas no Sul da Bahia e são geograficamente distantes de Salvador (865 km e $446 \mathrm{~km}$, respectivamente).

Também nesse grupo estão Alagoinhas, no Nordeste baiano, próxima a Salvador e à região do Recôncavo (a $108 \mathrm{~km}$ da capital), Itaberaba, situada no Centro-Norte do Estado da Bahia e também menos distante da capital $(276 \mathrm{~km})$, e Seabra, na área da Chapada Diamantina, Centro-Sul da Bahia (a $456 \mathrm{~km}$ de Salvador).

No grupo seguinte, estão cinco cidades com pesos próximos à neutralidade (em torno de 0,50). Seria possível afirmar que nessas localidades, situadas em diferentes porções do Estado - Jacobina (Centro Sul), Caetité (Centro Sul), Valença (Sudeste), Barreiras (Oeste) e Euclides da Cunha (Nordeste) -, o fenômeno não é favorecido, mas também não é fortemente inibido pelos falantes, limitando-se a contextos linguísticos específicos.

Por fim, no último grupo, estão 10 das 22 cidades consideradas (Juazeiro, Santa Cruz Cabrália, Jequié, Irecê, Barra, Jeremoabo, Itapetinga, Carinhanha, Santana e Vitória da Conquista). Essas áreas se caracterizam por pesos baixos para a ditongação, havendo alguns casos em que o fenômeno é praticamente improvável. São destaques, nesse sentido: Carinhanha, no Sudoeste da Bahia; Santana, no extremo Oeste do Estado; e Vitória da Conquista, no Sudoeste; com pesos de 0,23, 0,20 e 0,19, respectivamente. Nessas localidades as vogais não ditongadas parecem ser a regra.

\section{CONSIDERAÇÕES FINAIS}

Este trabalho teve por objetivo a investigação da distribuição diatópica da ditongação diante de $<\mathrm{S}>$ no Estado da Bahia. Propôs-se, nesse sentido, a apresentação dos resultados segundo as premissas da Geolinguística, valendo-se das cartas linguísticas como principal fonte de exposição dos dados. Foram comentados, brevemente, aspectos da Dialetologia no Brasil e na Bahia, destacando as inovações do Projeto ALiB, no que concerne à cartografia dos dados linguísticos.

O trabalho partiu do pressuposto de que esse tipo de ditongação é uma inovação do $\mathrm{PB}$ e de que, mediante os resultados previamente encontrados para Salvador e outras capitais do Nordeste brasileiro, seria um traço típico da fala de determinadas regiões do país, sendo provável o seu papel de delimitador de áreas dialetais. Ao estudar os dados do Projeto ALiB para as cidades baianas, verificou-se o entorno geográfico imediato de Salvador, trazendo à luz mais indícios sobre o status desse fenômeno no português do Brasil.

Primeiro, os resultados obtidos por meio das seis questões do QFF permitiram evidenciar que a ditongação diante de $<\mathrm{S}>$ é condicionada tanto pela qualidade da vogal quanto pela distribuição diatópica. No que concerne à diatopia, foi visto, desde essa 
primeira análise, que cidades como Vitória da Conquista, Carinhanha e Santana demonstrariam restrições às vogais ditongadas. Por outro lado, cidades litorâneas, dentre as quais se destacam Salvador e Santo Amaro, no entorno da Baía de Todos os Santos, revelaram tendência à ditongação diante de $<\mathrm{S}>$.

Por meio dos pesos relativos, foi revelada a existência de quatro diferentes comportamentos para as cidades baianas, com relação ao fenômeno em análise. No grupo de cidades em que os pesos pertinentes à ditongação são elevados, são, mais uma vez, proeminentes Salvador e Santo Amaro, que guardam em comum, além do trânsito de indivíduos no passado e na atualidade, características sociais e vivências ao longo de mais de cinco séculos de história. Dentre estas, citam-se a massiva presença dos povos e línguas africanas, durante o período colonial e, na atualidade, a expressividade do contingente afrodescendente. Trata-se não somente de um legado histórico em comum mas também de um fluxo de valores culturais e, aparentemente, traços linguísticos perceptíveis nesta sincronia.

No grupo de cidades em que os informantes restringem a ditongação, estão Vitória da Conquista e Carinhanha, que se distanciam não só geograficamente da capital e da área do Recôncavo Baiano mas também se apartam das interferências socioculturais de Salvador. Ademais, essas são cidades marcadas pelas entradas e bandeiras, vindas do Sudeste, no passado, e pelo contato entre elas e as Minas Gerais, no presente. Vitória da Conquista, em específico, configura-se como um grande centro urbano no Sudoeste da Bahia, estando presentes naquela cidade uma universidade pública estadual, um campus da UFBA, um instituto federal, além de instituições de ensino privadas, hospitais, comércios e outras instâncias que lhe dão destaque na região. Essa cidade, assim, não parece sofrer as influências linguísticas da capital.

A observação de aspectos históricos, étnicos e culturais permite que se entenda que, embora não seja possível traçar, com clareza, isoglossas pertinentes à ditongação diante de $<\mathrm{S}>$ na Bahia, é possível considerar a existência de zonas dialetais diferenciadas. Os resultados obtidos para as áreas mais litorâneas e suas interpretações são reforçados quando são verificados os dados das capitais brasileiras (SILVA, 2014), em especial aqueles vistos em Maceió e Recife.

Por outro lado, os comportamentos das cidades do Sudoeste e do Oeste baianos (como Barreiras, Barra e Santana, por exemplo) se relacionam com aqueles vistos nas capitais do Centro-Oeste do Brasil e em Belo Horizonte. Ademais, a conexão proporcionada pelo Rio São Francisco entre as Minas Gerais e cidades como Carinhanha, Santana, Barra e Juazeiro também deve ser considerada, quando levamos em conta a restrição encontrada pelo fenômeno nessas cidades e na capital mineira. A investigação das cidades do Norte do Estado de Minas, nesse sentido, poderia fornecer uma visão mais clara dessa situação.

Por fim, há a compreensão de que os comportamentos encontrados para o fenômeno nas cidades baianas são frutos de movimentos sociais diversos, ocorridos no espaço da Bahia, no curso de sua história. Esses fluxos e ressonâncias são relativos ao próprio processo de difusão da língua portuguesa no Brasil e ganham reforços nos panoramas sociais, econômicos e culturais avistados nessas cidades atualmente. 


\section{REFERÊNCIAS}

BISOL, Leda. O clítico e seu status prosódico. Revista Estudos Lingüisticos, Belo Horizonte, v. 9, n. 1, p. 5-30, 2000.

CALLOU, Dinah; LEITE, Yonne; MORAES, João. Processos em curso no Português do Brasil: a ditongação. In: HORA, Dermeval; COLLISCHONN, Gisela. Teoria lingüistica: fonologia e outros temas. João Pessoa: UFPB, 2003a, p. 232-250.

CALLOU, Dinah; LEITE, Yonne; MORAES, João. Processos de mudança no português do Brasil: variáveis sociais. In: CASTRO, Ivo; DUARTE, Inês (Orgs.). Razões e emoção: miscelânea de estudos em homenagem a Maria Helena Mira Mateus. v.1. Lisboa: Imprensa Nacional, Casa da Moeda, 2003b, p. 87-95.

CALLOU, Dinah; LEITE, Yonne; MORAES, João. A ditongação no português do Brasil: estudo de dois casos. CONGRÈS INTERNATIONAL DE LINGUISTIQUE ET DE PHILOLOGIE ROMANES, XXII, 1998, Bruxelles, Actes..., Bruxelles: De Gruyter, p. 95-101, 1998.

CÂMARA JR., Joaquim Mattoso. Para o estudo da fonêmica portuguesa. $2^{\mathrm{a}}$ ed. Petrópolis: Vozes, 2008 [1953].

CARDOSO, Suzana Alice Marcelino da Silva et al. Atlas linguístico do Brasil: Introdução. v. 1. Londrina: EDUEL, 2014a.

CARDOSO, Suzana Alice Marcelino da Silva et al. Atlas linguístico do Brasil: Cartas linguísticas. v. 2. Londrina: EDUEL, 2014b.

COMITÊ NACIONAL. Atlas lingüístico do Brasil: Questionários 2001. Londrina: EDUEL, 2001.

COUTINHO, Ismael de Lima. Gramática histórica. 6a ed. rev. 7. reimp. Rio de Janeiro: Livraria Acadêmica, 1974 [1938].

HAUPT, Carine. Sibilantes coronais - o processo de ditongação e palatalização em sílabas travadas na fala de florianopolitanos nativos: uma análise baseada na Fonologia de Geometria de Traços. 2007. Dissertação (Mestrado em Linguística) - Universidade Federal de Santa Catarina (UFSC). Florianópolis: UFSC, 2007.

HAUPT, Carine. A ditongação em sílabas fechadas por /S/ em Florianópolis. ENCONTRO DO CÍRCULO DE ESTUDOS LINGUISTICOS DO SUL, 7, 2006, Pelotas, Anais... Pelotas: EDUCAT, 2008, p. 1-6. Disponível em: <http://www.celsul.org.br/Encontros/07/dir2/1.pdf>. Acesso em: out. 2010.

LEIRIA, Lúcia Lovato. A ditongação variável em sílabas tônicas finais travadas por /S/. Organon, v. 14, n. 28-29, p. 133-141, 2000.

LEIRIA, Lúcia Lovato. A ditongação variável em sílabas tônicas travadas por / S/. 1995. 74 p. Dissertação (Mestrado em Letras). Pontifícia Universidade Católica do Rio Grande do Sul. Porto Alegre, março de 1995.

RIBEIRO, Marana de Almeida Moreira. A palatalização das oclusivas dentoalveolares antes de [i] no interior baiano. 2018. Dissertação (Mestrado em Língua e Cultura) - Universidade Federal da Bahia (UFBA). Salvador: UFBA, 2018. 


\section{Revista

ROBINSON, John; LAWRENCE, Helen; TAGLIAMONTE, Sali. Goldvarb 2001: a multivariate analysis application for Windows. Nova York: University of York, 2001.

ROSSI, Nelson. Atlas prévio dos falares baianos. Rio de Janeiro: MEC/INL,1963.

SANTANA, Isamar Neiva de. Vocabulário dialetal baiano. 2017. Tese (Doutorado em Língua e Cultura) - Universidade Federal da Bahia (UFBA). Salvador: UFBA, 2017.

SILVA NETO, Serafim da. Introdução ao estudo da lingua portuguêsa no Brasil. $2^{\mathrm{a}}$ ed. revista e aumentada. Rio de Janeiro: Instituto Nacional do Livro, 1963.

SILVA, Amanda dos Reis. A ditongação em sílabas fechadas por /S/ nas trilhas das capitais brasileiras. 2014. Dissertação (Mestrado em Língua e Cultura) - Universidade Federal da Bahia (UFBA). Salvador: UFBA, 2014.

SILVA, Amanda dos Reis. Ditongação diante de $<S>$ na Babia: distribuição dialetal e variação fonético-fonológica. 2018. Tese (Doutorado em Língua e Cultura) - Universidade Federal da Bahia (UFBA). Salvador: UFBA, 2018.

SOUSA DA SILVEIRA, Álvaro. Lições de português. $4^{a}$ ed. São Paulo: Companhia Editora Nacional, 1940.

TASCA, Maria. A inserção de glide em sílaba travada por /S/. Letras de Hoje, v. 40, n. 3, Porto Alegre, p. 137-162, 2005.

TELES, Ana Regina Torres Ferreira; RIBEIRO, Silvana Soares Costa. A cartografia dos dados. In: CARDOSO, Suzana Alice Marcelino da Silva et al. Atlas linguístico do Brasil: Introdução. v. 1. Londrina: EDUEL, 2014, p.113-123.

VASCONCELOS, José Leite de. Esquisse d'une dialectologie portugaise. $2^{\mathrm{a}}$ ed. Centro de Estudos Filológicos: Lisboa, 1970 [1901]. 